\title{
Towards Intra-population Improvement of Alfalfa Yield and Persistence
}

\author{
Dragan Milić · Snežana Katanski · Đura Karagić · Sanja Vasiljević · \\ Branko Milošević · Ksenija Taški-Ajduković · Nevena Nagl
}

Institute of Field and Vegetable Crops, Maksima Gorkog 30, 21000 Novi Sad, Serbia

\begin{abstract}
Summary: Alfalfa (Medicago sativa L.) is the most important forage crop in the world, regarding growing area and economic value, because of its high yield level, good persistence, high protein content and energy value. In alfalfa, concept of intra-population breeding means direct selection for yield, through recurrent phenotypic selection using some form of progeny testing. Significant differences between genotypes were found for green forage and dry matter yields. The observed variation for both yield traits was much higher at population level than for the selected plants that will form new improved population. In the next steps of breeding process selected plants will be intercrossed in isolation to develop a new, improved population. Alfalfa breeding programs should focus on yield per se, with the use of old and new knowledge on the genetic control of yield and with adaptation of existing or developing new breeding procedure.

Key words: alfalfa, breeding, crop yield, intra-population improvement, persistence
\end{abstract}

\section{Introduction}

Alfalfa (Medicago sativa L.) is the most important forage crop in the world (Michauld et al. 1988), as well as in Serbia (Milić et al. 2014), regarding both growing area and economic value (Bouton 2007). It is an autotetraploid, allogamous and self-incompatible plant species, which means that each cultivar is a heterogeneous population with heterozygous individuals (genotypes). In alfalfa, the common approach in breeding programs involves recurrent phenotypic selection with or without progeny testing, in order to accumulate desirable alleles at high frequency into a population. Also, yield improvement of alfalfa is the main target in all public and private breeding programs (Li \& Brummer 2012).

The progress of alfalfa breeding has been slow, mostly due to its complex genetic structure (autotetraploidy), allogamy and tetrasomic inheritance. The idea on partial utilization of heterosis in alfalfa that emerged in the USA proposed the development of semi -hybrids obtained by crossing genetically divergent germplasms and identifying heterotic groups (Brummer 1999). Li \& Brummer (2012) suggested that alfalfa breeders should create heterotic groups de novo.

Corresponding author:

dragan.milic@ifvens.ns.ac.rs

Acknowledgements:

This study was funded by the Serbian Ministry of Education, Science and Technological Development within the project TR 31024.
Beginning of the process with adapted, newly created elite populations avoids the problem of germplasm, deficient in many necessary attributes, and enables the generation of desirable hybrids from the beginning. Intrapopulation breeding in alfalfa presents refined version of mass selection, with the main goal to improve the mean genotypic value of a single population. After one cycle of selection, the mean genotypic value can be expressed as change in allele frequency (Rowe \& Hill 1984).

The concept of intrapopulation breeding in alfalfa means direct selection for yield, through recurrent phenotypic selection using some form of progeny testing in one population, with no less than 1200 plants. Intrapopulation breeding leads to the accumulation of desirable alleles, i.e. to additive gene action, and helps the improvement of populations with a narrow genetic base (Milić et al. 2013). Casler \& Brummer (2008) suggest that using within family selection in single plant nursery, with one population and one species requires no less than 400 plants per family. In cold regions of Serbia, it is very important to work on improving of persistence in order to reduce stand loss. Recurrent phenotypic selection (RPS) in alfalfa is limited (i) by the size of breeding populations evaluated in the field, (ii) low heritability of important traits, $G \times E$ interactions that are difficult to assess due to limited testing resources in most breeding programs, and (iii) phenotypic evaluations themselves that require multiple harvests per year for multiple years in order to estimate/evaluate persistence (Li \& Brummer 2012). 
All of these obstacles make alfalfa selection less efficient than in many annual field and vegetable crops. Objectives of this study were: i) to improve agronomic performance of population Niagara in environmental conditions of the Pannonian plain, with main target to create material desirable for growing in more intensive cutting systems; ii) to develop new population with narrow genetic base in order to make it more adaptive and stable in certain environmental conditions; and iii) to evaluate potential of newly created germplasm to serve as a heterotic group in alfalfa semi hybrid breeding program.

\section{Materials and Methods}

\section{Plant material}

Trial with 1246 plants in alfalfa population cv. Niagara was established in spring of 2012. Niagara is alfalfa cultivar prone to grow in mountain regions, on heavy, hydromorphic, acid soils after application of lime (Milić et al. 2014). Niagara plants were evaluated through 9 cuts during 2013 (5 cuts) and 2014 (4 cuts), in the second and third year of plant life. Plants were sown in single plant nursery, in 22 rows with $80 \mathrm{~cm}$ apart between rows and $25 \mathrm{~cm}$ between plants in row. The following traits were analysed: green forage yield ( $\mathrm{g}$ plant $\left.{ }^{-1}\right)$; dry matter yield $\left(\mathrm{g}\right.$ plant $\left.{ }^{-1}\right)$ and plant height $(\mathrm{cm})$ at the moment of cutting. In order to determine dry matter yield per plant, samples (200 g) were taken in every cut (3 samples per cut) and dried at $70^{\circ} \mathrm{C}$ for 48 hours. Plants were harvested at the beginning of flowering (recommended phenophase for cutting in Serbian environmental conditions). Values for every trait were calculated in both years separately (2013-2014) as average performance of every plant during 5 cuts in 2013 and four cuts during 2014.

\section{Statistical analysis}

Statistical analysis was accomplished in Microsoft Excel. Excel-based calculations were presented using standard statistic observations: mean, maximum and minimum values, standard deviation and coefficient of variation, at the population level, and for selected plants.
Plants were selected upon a base of average performance of population in green and dry matter yields in both years, and on mean values was added measure of standard deviation, obtained separately for each year (2013-2014).

\section{Results and Discussion}

This study was conducted in order to determine the possibilities of improving yield and persistence of alfalfa population, using intrapopulation breeding methods (within family selection). There was huge variation in Niagara population for selected traits (Tables 1 and 2). On average over the five cuts of 2013, population's green forage yield ranged from $12 \mathrm{~g} \mathrm{plant}^{-1}$ up to $833 \mathrm{~g} \mathrm{plant}^{-1}$, while average yield was $376.7 \mathrm{~g} \mathrm{plant}^{-1}$ (Table 1). Dry matter yield varied from $3.4 \mathrm{~g}$ plant $^{-1}$ up to $279.3 \mathrm{~g}$ plant $^{-1}$, with average yield of $122.7 \mathrm{~g} \mathrm{plant}^{-1}$. The plant height ranged from $35.2 \mathrm{~cm}$ to $92 \mathrm{~cm}$, with an average of 70.3 $\mathrm{cm}$. Coefficient of variation $(\mathrm{CV})$ in population Niagara for green forage and dry matter yield were $34.7 \%$ and $35.7 \%$, and for plant height $11.8 \%$.

In order to quantify amount of variation and to select the most vigorous plants, standard deviation (SD) was calculated for every trait. In 2013, values of SD for green forage were $130.9 \mathrm{~g}$, for dry matter yield $12.3 \mathrm{~g}_{\text {plant }}{ }^{-1}$, and for plant height $8.3 \mathrm{~cm}$. By using the calculation: average yield + SD value, we selected 187 plants, with improved performance of every trait in a given year of trial. Average yield of green forage and dry matter yield in selected plants were 575.0 and $187.8 \mathrm{~g}$ plant $^{-1}$. Minimum values of selected plants were 508 and $138 \mathrm{~g} \mathrm{plant}^{-1}$, respectively. Variation measurements $(\mathrm{CV})$ in the population of selected plants $(11.6 \%$ and $12.6 \%$ for yield traits) were much lower than in core population of Niagara (because we excluded more than $50 \%$ of the plants). These results present the very first step in development of high yielding population in the future with narrower genetic base using simple selection procedure. Our results indicate that selection of the plants in second year can lead to direct yield improvement.

Table 1. Mean, minimum and maximum values, standard deviation and coefficient of variation, of observed traits in alfalfa population and selected plants on average over the five cuts of 2013

\begin{tabular}{|c|c|c|c|c|c|c|c|c|c|c|}
\hline \multirow[t]{2}{*}{ Trait } & \multicolumn{5}{|c|}{$\begin{array}{l}\text { Population performance } \\
\text { (1246 plants) in } 2013\end{array}$} & \multicolumn{5}{|c|}{$\begin{array}{l}\text { Selected plants performance } \\
\text { (187 plants }) \text { in } 2013\end{array}$} \\
\hline & Mean & Max. & Min. & $\mathrm{SD}$ & $\mathrm{CV}$ & Mean & Max. & Min. & $\mathrm{SD}$ & $\mathrm{CV}$ \\
\hline GFY g plant ${ }^{-1}$ & 376.7 & 833.0 & 12.0 & 130.9 & 34.7 & 575.0 & 833.0 & 508.0 & 66.6 & 11.6 \\
\hline DMY g plant ${ }^{-1}$ & 122.7 & 279.3 & 3.4 & 12.3 & 35.7 & 187.8 & 279.3 & 138.0 & 22.5 & 12.0 \\
\hline $\mathrm{PH}(\mathrm{cm})$ & 70.3 & 92.0 & 35.2 & 8.3 & 11.8 & 76.1 & 89.0 & 62.6 & 5.2 & 6.9 \\
\hline
\end{tabular}

*GFY - Green forage yield; DMY-dry matter yield; PH - plant height 
Table 2. Mean, minimum and maximum values, standard deviation and coefficient of variation of observed traits in alfalfa population and selected plants on average over the four cuts of 2014

\begin{tabular}{|c|c|c|c|c|c|c|c|c|c|c|}
\hline \multirow[t]{2}{*}{ Trait } & \multicolumn{5}{|c|}{$\begin{array}{l}\text { Population performance } \\
\text { (1246 plants) in } 2014\end{array}$} & \multicolumn{5}{|c|}{$\begin{array}{l}\text { Selected plants performance } \\
\text { (183 plants) in } 2014\end{array}$} \\
\hline & Mean & Max. & Min. & $\mathrm{SD}$ & $\mathrm{CV}$ & Mean & Max. & Min. & SD & $\mathrm{CV}$ \\
\hline GFY g plant ${ }^{-1}$ & 300.6 & 897.5 & 7.5 & 142.4 & 47.4 & 522.3 & 897.5 & 305.0 & 67.9 & 13.0 \\
\hline DMY g plant ${ }^{-1}$ & 77.3 & 234.3 & 1.8 & 36.9 & 47.8 & 134.8 & 234.3 & 79.4 & 18.2 & 13.5 \\
\hline $\mathrm{PH}(\mathrm{cm})$ & 75.4 & 105.8 & 31.0 & 12.7 & 16.9 & 87.1 & 105.3 & 61.8 & 8.5 & 9.7 \\
\hline
\end{tabular}

*GFY - Green forage yield; DMY-dry matter yield; PH - plant height

In 2014, slightly lower mean values of examined traits were recorded comparing to the previous year, but with much higher values of coefficients of variation: $47.4 \%$ for green forage yield, $47.8 \%$ for dry matter yield, and $12.7 \%$ for plant height, respectively (Table 2). Higher level of variation in third year of plant life can be explained due to intensive cutting system applied in 2013, but also because of different climatic conditions and years of utilization during examination. Using selection procedure previously described, we de novo selected 183 plants with average yield of green forage of $522.3 \mathrm{~g}$ plant $^{-1}$, and dry matter of $134.8 \mathrm{~g}$ plant $^{-1}$, with plant height of $87.1 \mathrm{~cm}$. Selection process included 74 plants that were also selected in 2013.

Minimum values for green forage, dry matter yield and plant height in selected plants (305.0 g plant $^{-1}, 79.4$ $\mathrm{g}$ plant $^{-1}$, and $87.1 \mathrm{~cm}$ respectively) were higher for a two standard deviation than minimum values at a whole population level $\left(7.5 \mathrm{~g} \mathrm{plant}^{-1}, 1.8 \mathrm{~g}\right.$ plant $\left.^{-1}, 31.0 \mathrm{~cm}\right)$. Variation of 183 selected plants in 2014 was much lower for yield traits $(13.0 \%$ and $13.5 \%)$ than at Niagara population level.

Alfalfa breeders should carefully design and establish breeding programs to make selection more efficient, which will lead to maximization of expected gains within capabilities and goals of the programs (Casler \& Brummer 2008). Selection after the third year of plant life resulted in a choice of plants with higher level of persistence and improved yield. Plants selected during this evaluation will be intercrossed in isolation to develop a new, improved population in the next steps of a breeding procedure. In which direction selection will be made (yield or persistence, or both) depends on the breeder's choice, but more likely on the environmental conditions where the selection program is based.

\section{Next steps}

In the following period, plants selected on the basis of the field test data after third year of plant life, will be crossed in space isolation to produce seed and form the new, improved population. Newly created population will be multiplied in polycross to undergo progeny testing, and further comparison with initial Niagara population and other commercial varieties. Selected population should be dominantly formed from progenies of plants that perform well in both study years (2013 and 2014), which means that selection was made on both criteria yield and persistence.

DNA markers (SSR) should be applied in order to check homogeneity and to insure development of more uniform genetic material. The final step should be registration of new population with improved agronomic performance, and with narrow genetic base which can be used as variety for commercial purposes or used as heterotic group in semi hybrid breeding strategies as Brummer et al. (1999) proposed.

\section{Conclusions}

Alfalfa breeding programs that focus on yield per se should use old and new knowledge on the genetic control of yield and adapt existing or create new breeding procedure. Selection of plants based on results of the second year of plant life should be in direct function of yield improvement, but selection after the third year leads to a better persistence. Our results demonstrate possible success of within family selection (intrapopulation breeding) method in alfalfa breeding. Even though such approach is necessarily long term, and hardworking process, progress in alfalfa breeding for yield can be achieved.

\section{References}

Bouton, J. (2007). The economics of forage improvement in the United States. Euphytica, 154: 263-270. doi: 10.1007/s10681-0069220-6.

Brummer, E.C. (1999). Capturing heterosis in forage crop cultivar development. Crop Sci, 39: 943-954.

Brummer, E. C., Luth, D., \& Riday, H. (1999). Breeding for Heterosis Using Traditional and Marker Assisted Methods. The Alfalfa Genome, 1-4 August, Madison, Wisconsin. Retrieved from: www.naaic.org.

Casler, M. D., \& Brummer, E. C. (2010). Theoretical expected genetic gains for among- and within-family selection methods in perennial forage crops. Crop Sci. 48: 890-902.

Li, X., \& Brummer, E.C. (2012). Applied Genetics and Genomics in Alfalfa Breeding. Agronomy, 2: 40-61. 
Michaud, R., Lehnan, W. F., \& Raumbaugh, M. D. (1988). World distribution and historical development. Alfalfa and alfalfa improvement. In: A. A. Hanson, D. K. Barnes, and R. R. Hill Jr. (eds.) Alfalfa and Alfalfa Improvement. ASA-CSSA-SSSA, Madison Wisconsin, USA, pp. 25-124

Milić, D., Taški-Ajduković, K., Nagl, N., Katanski, S., \& Katić, S. (2013). Heterosis in alfalfa breeding. Ratar. Pourt. 50(3): 60-64 doi: $10.5937 /$ ratpov50-5059.
Milić, D., Katić, S., Katanski, S., Dugalić, G., Bokan, N., \& Vasiljević, S. (2014). Effect of Genotype and Applied Management on Alfalfa Yield and Quality. Ratar. Povrt. 51(2): 91-99. doi:10.5937/ ratpov51-5571

Rowe, D. E., \& Hill, R. R. Jr. (1984). Theoretical Improvement of Autotetraploid Crops: Interpopulation and Intrapopulation Selection. United States Department of Agriculture, Technical Bulletin No. $1689,32 \mathrm{p}$.

\section{Intrapopulaciono poboljšanje prinosa i dužine života lucerke \\ Dragan Milić · Snežana Katanski · Đura Karagić · Sanja Vasiljević . Branko Milošević · Ksenija Taški-Ajduković · Nevena Nagl}

Sažetak: Lucerka (Medicago sativa L.) je najvažnija krmna bilika u svetu, kako sa stanovišta površina koje zauzima tako i njene ekonomske vrednosti predstavljene kroz visok prinos, trajnost (dužinu života), odličan kvalitet i energetsku vrednost. Koncept intrapopulacionog oplemenjivanja kod lucerke podrazumeva direktnu selekciju na prinos primenom rekurentne fenotipske selekcije uz korišćenje testova potomstava. Značajne razlike između genotipova su zabeležene za prinos zelene krme i suve materije. Variranje osobina prinosa je bilo značajno veće na nivou cele populacije nego kod odabranih biljaka. Budući koraci u oplemenjivanju lucerke su sledeći: odabrane biljke će se umnožavati u izolaciji sa ciljem stvaranja nove, popravljene populacije. Novostvorena populacija će se testirati sa nekim od progenih testova i porediti sa početnom populacijom (sorta Nijagara) i komercijalnim sortama lucerke. Nova populacija biće testirana DNK markerima u cilju provere homogenosti, tj. u cilju provere genetičke ujednačenosti. Programi oplemenjivanja lucerke trebalo bi da se fokusiraju na prinos per se, uz korišćenje starih i novih znanja vezanih za genetičku kontrolu agronomski važnih osobina, uz adaptaciju postojećih i razvoju novih oplemenjivačkih procedura.

Ključne reči: intrapopulaciono poboljšanje, lucerka, oplemenjivanje, prinos, trajnost 